\title{
Effect of pH on Toxicity of Copper to Scytalidium sp., a Copper- tolerant Fungus, and Some Other Fungi
}

\author{
By R. L. STARKEY \\ Department of Biochemistry and Microbiology, College of Agriculture and \\ Environmental Science, Rutgers University, The State University of New Jersey, \\ New Brunswick, New Jersey 08903, U.S.A.
}

(Received I8 September I972; revised 30 April I973)

\section{SUMMARY}

Scytalidium sp. grew in acidic media $(\mathrm{pH} 2 \cdot 0$ to 0.3$)$ saturated with copper sulphate (approx. I M) but was sensitive to low concentrations of copper $\left(4 \times 10^{-5} \mathrm{M}\right)$ near neutrality. Eleven other fungi differed in that they tolerated relatively high concentrations of copper near neutrality; nine tolerated high concentrations from $\mathrm{pH} 3.0$ to $7 \cdot 0$, and six tolerated $4 \times \mathrm{IO}^{-3} \mathrm{M}$-copper sulphate at $\mathrm{pH} 2.0$ to 7.0 . Oxine was more toxic to Scytalidium sp. at neutrality than it was at an acid $\mathrm{pH}$ and in the presence of relatively large amounts of copper. EDTA had no appreciable effect on toxicity of copper. The fungus was relatively tolerant to chlorides of iron, cobalt and chromium at both neutral and acid $\mathrm{pH}$.

\section{INTRODUCTION}

Although copper is toxic to most fungi (Horsfall, 1956), some fungi are remarkably tolerant to it. Cultures of Penicillium and Aspergillus species can grow in media saturated or nearly saturated with copper sulphate (Trabut, I895; Pulst, I902; Bedford, 1936; Hubert, I938; Sato, I939; Jurkowska, I952). Other fungi can grow in media containing from I \% to $15 \%$ copper sulphate (Brooks, I9I4) or copper ammonium citrate (Villedieu \& Villedieu, 1920). Bacteria are less tolerant to copper, but copper tolerance of the autotrophic sulphur bacteria Thiobacillus thiooxidans, $T$. ferrooxidans and $T$. concretivorus is outstanding in that adapted strains withstand up to 0.12 to 0.23 M-copper sulphate (Booth \& Mercer, I963). The first two cultures oxidize copper sulphide ores, so resulting in production of acid which dissolves the copper (Bryner, Beck, Davis \& Wilson, I954; Marchlewitz, Hasche \& Schwarz, 1961; Sutton \& Corrick, I963; Kuznetsov, Ivanov \& Lyalikova, 1963).

Starkey \& Waksman (1943) reported that two fungi, isolated from acid solutions ( $\mathrm{pH} 0.2$ to 0.7 ) containing $4 \%$ copper sulphate, could grow in media saturated with copper sulphate and having a $\mathrm{pH}$ close to $\mathrm{o}$. Studies of the influence of $\mathrm{pH}$ on toxicity of copper have been made with one of these cultures, a species of Scytalidium (Ellis, 197I) previously designated Fungus D, as well as other fungi. The effect of the chelating agents, oxine (8-hydroxyquinoline) and EDTA (ethylenediaminetetra-acetic acid) on toxicity of copper to Scytalidium sp., and the influence of salts of iron, cobalt and chronium on development of the fungus, have been determined.

\section{METHODS}

Cultures of the Scytalidium sp. have been deposited in the following culture collections: Commonwealth Mycological Institute, Surrey; Centraalbureau voor Schimmelcultures, 
Baarn, Netherlands; American Type Culture Collection, Rockville, Maryland, U.S.A.; Northern Marketing and Nutritional Research Division, A.R.S., U.S.D.A., Peoria, Illinois, U.S.A.; Mold Herbarium and Culture Collection, University of Alberta, Edmonton, Alberta, Canada (no. UAMH 3489). J. W. Carmichael of the University of Alberta identified Fungus D as a new species of the genus Scytalidium and intends to publish the description.

The fungus was maintained on the following medium (g/l): glucose, Io; $\left(\mathrm{NH}_{4}\right)_{2} \mathrm{SO}_{4}, 0.5$; $\mathrm{KH}_{2} \mathrm{PO}_{4}, 0.5 ; \mathrm{K}_{2} \mathrm{HPO}_{4}, 0.5 ; \mathrm{MgSO}_{4} .7 \mathrm{H}_{2} \mathrm{O}, 0 . \mathrm{I} ; \mathrm{CaCl}_{2} .2 \mathrm{H}_{2} \mathrm{O}, 0 . \mathrm{I} ; \mathrm{FeSO}_{4} \cdot{ }_{7} \mathrm{H}_{2} \mathrm{O}, 0.0 \mathrm{I}$; distilled water to $1000 \mathrm{ml}$. The glucose was sterilized separately. The fungus grew well in this medium with initial $\mathrm{pH}$ values of 7.0 to 0.5 , and made some growth at $\mathrm{pH}$. The medium became increasingly acid during growth; as tolerance to copper was greater at low $\mathrm{pH}$, it was difficult to establish the influence of $\mathrm{pH}$ on copper toxicity. To overcome this difficulty, $\mathrm{NaNO}_{3}$ containing an equivalent amount of nitrogen was substituted for $\left(\mathrm{NH}_{4}\right)_{2} \mathrm{SO}_{4}$ in media for cultivation of Scytalidium sp. except in the first experiment (Table I). The copper was added as $\mathrm{CuSO}_{4} \cdot 5 \mathrm{H}_{2} \mathrm{O}$. When oxine was used it was dissolved and sterilized in ethanol, and appropriate dilutions in water were added to sterile media. The $125 \mathrm{ml}$ Erlenmeyer culture flasks contained a final volume of $50 \mathrm{ml}$ of medium after all constituents had been added. The media were inoculated with portions of 7-to I4-day-old fungus pellicles grown on the glucose-nitrate solution medium. Preliminary tests provided no evidence that cultivation of Scytalidium sp. in medium containing $0 . \mathrm{I}$ M-copper sulphate increased its tolerance to copper. The inoculated media were static during incubation at $28{ }^{\circ} \mathrm{C}$.

The effect of copper on growth of the following filamentous fungi was determined also: Aspergillus flqus, $A$. niger, $A$. oryzae, Penicillium notatum, $P$. simplicissimum, Trichoderma koningi, Fusarium oxysporum, F. culmorum, Monilinia fructicola, Stemphylium sarcinaeforme and Rhizopus nigricans. The cultures of $M$. fruticola and $S$. sarcinaeforme were generously provided by J. G. Horsfall of the Connecticut Agricultural Experiment Station, New Haven, Connecticut, U.S.A. The other fungi came from the culture collection of the Department and most had been isolated from soil. Some of these fungi grew poorly or produced acid when grown in the glucose-nitrate medium. The following changes in medium composition resulted in good growth, and the $\mathrm{pH}$ of the media increased during growth. In the medium for $A$. niger and $R$. nigricans $0 \cdot \mathrm{I} \%(\mathrm{w} / \mathrm{v}) \mathrm{L}$-asparagine was substituted for nitrate and $\mathrm{I} \cdot 0 \%$ $(\mathrm{w} / \mathrm{v}) \mathrm{Na}$-lactate and $0.5 \%(\mathrm{w} / \mathrm{v})$ glucose were the sources of carbon. For $M$. fructicola $0 . \mathrm{I} \%(\mathrm{w} / \mathrm{V}) \mathrm{L}$-asparagine was used as the source of nitrogen, $\mathrm{I} \cdot 0 \%(\mathrm{w} / \mathrm{v}) \mathrm{Na}$-succinate and $0.5 \%(\mathrm{w} / \mathrm{v})$ glucose were the sources of carbon and $0.05 \%(\mathrm{w} / \mathrm{v})$ yeast extract was added. For $S$. sarcinaeforme $0.1 \%(\mathrm{w} / \mathrm{v}) \mathrm{L}$-asparagine was used as the source of nitrogen.

Since addition of relatively large amounts of copper sulphate increased the acidity of the media, alkali was added to adjust the $\mathrm{pH}$. Much of the copper in media with more than $4 \times 10^{-5} \mathrm{M}$-copper sulphate and having $\mathrm{pH} 5^{\circ} \mathrm{O}$ to $7^{\circ} \mathrm{O}$ became precipitated as copper hydrate, and there was some precipitate at $\mathrm{pH} 4 \cdot 0$ to $5 \cdot 0$. To avoid interference from the precipitate when the mycelia were harvested, 3 to $\mathrm{ro} \mathrm{ml}$ of $\mathrm{I} \mathrm{M}-\mathrm{HCl}$ was then added to the culture medium to dissolve the precipitate. The mycelium was collected on tared filter paper and was thoroughly washed before being dried to constant weight at I I ${ }^{\circ} \mathrm{C}$. The values for cell weight are averages of closely agreeing duplicate cultures. The cultures were generally incubated for 4 to 6 weeks.

\section{RESULTS}

\section{Effect of nitrogen sources on changes in $\mathrm{pH}$ and copper toxicity}

Scytalidium sp. grew at all the $\mathrm{pH}$ values tested in the absence of copper, and in the media with ammonium nitrogen that contained copper (Table I). The metal was somewhat toxic 


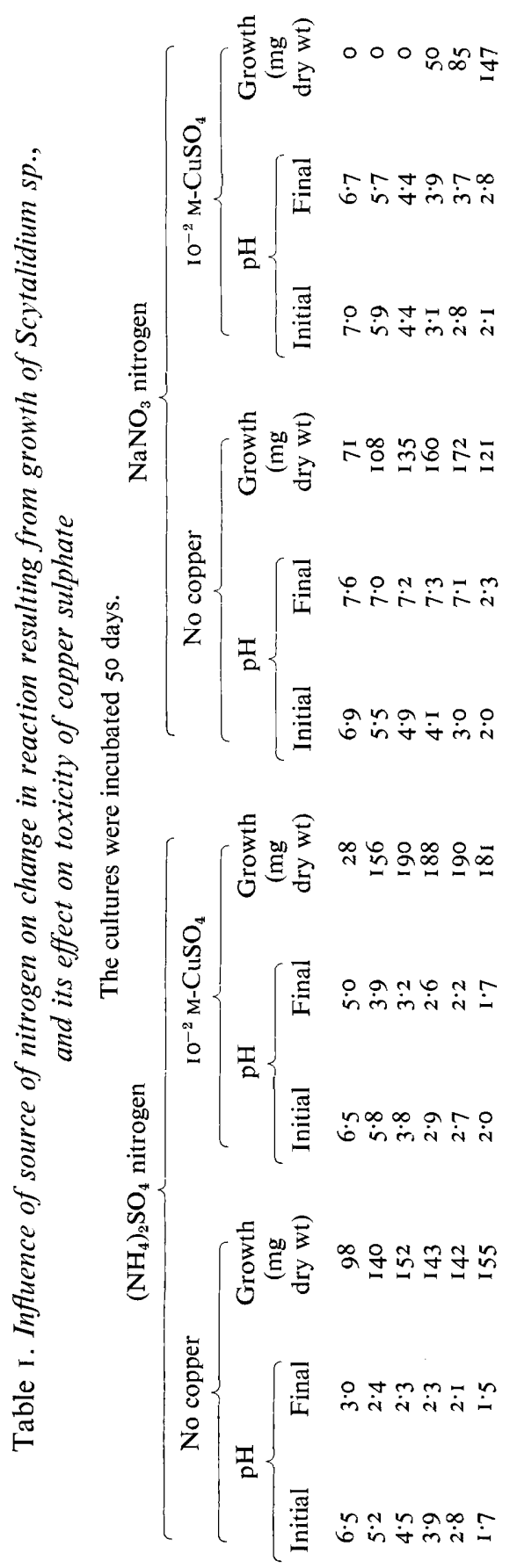


Table 2. Influence of reaction on toxicity of copper sulphate to Scytalidium sp.

$\mathrm{NaNO}_{3}$ was the nitrogen source. The cultures were incubated 34 days.

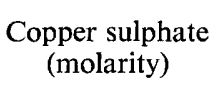

0

$4 \times 10^{-6}$

$4 \times 10^{-5}$

$4 \times 10^{-4}$

0

$4 \times 10^{-7}$

$4 \times 10^{-6}$

$4 \times 10^{-5}$

$4 \times 10^{-4}$

0

$4 \times 10^{-5}$

$4 \times 10^{-4}$

$4 \times 10^{-3}$

$4 \times 10^{-2}$

0

$4 \times 10^{-2}$
$\mathrm{pH}$

\begin{tabular}{cc}
\hline Initial & Final \\
$6 \cdot 8$ & $7 \cdot 7$ \\
$6 \cdot 9$ & $7 \cdot 5$ \\
$6 \cdot 7$ & $6 \cdot 8$ \\
$6 \cdot 7$ & $6 \cdot 7$ \\
$3 \cdot 7$ & $7 \cdot 0$ \\
$3 \cdot 9$ & $7 \cdot 0$ \\
$3 \cdot 9$ & $6 \cdot 6$ \\
$3 \cdot 9$ & $6 \cdot 3$ \\
$4 \cdot 0$ & $4 \cdot 7$ \\
$2 \cdot 9$ & $7 \cdot 5$ \\
$2 \cdot 8$ & $7 \cdot 4$ \\
$3 \cdot 0$ & $4 \cdot 7$ \\
$2 \cdot 9$ & $4 \cdot 2$ \\
$2 \cdot 8$ & $3 \cdot 1$ \\
$2 \cdot 1$ & $2 \cdot 3$ \\
$1 \cdot 9$ & $2 \cdot 0$
\end{tabular}

Growth

(mg dry wt)

I5I

I 25

I I

0
I 36

90

55

26

0
158

I 33

2 I

28

I0

103

89

near neutrality in the ammonium medium. The fungus did not grow at $\mathrm{pH} 4.4$ or above in the nitrate media containing copper and its growth was restricted at initial $\mathrm{pH}$ values of $2 \cdot 8$ and $3 \cdot 1$, but here growth resulted in an increase in $\mathrm{pH}$ to nearly 4.0 , which may have prevented further development.

\section{Effect of $p H$ on toxicity of copper to Scytalidium sp.}

Copper tolerance of this fungus is not lost readily, as there was no apparent change in resistance to high concentrations of copper in more than 20 years of cultivation on a medium devoid of added copper. A survey by Ashida (I965) indicated that acquired resistance to copper is relatively stable but that some cultures lost resistance when cultivated in absence of copper.

Scytalidium sp. was more resistant to copper in acid media (Table 2). The $\mathrm{pH}$ increased during growth in the nitrate-containing media except at initial $\mathrm{pH}$ values close to $2 \cdot 0$. Copper concentrations greater than $4 \times \mathrm{IO}^{-6} \mathrm{M}$ were strongly toxic or inhibitory near neutrality, although under these conditions much of the copper was precipitated, reducing the amount of soluble copper.

\section{Toxicity of copper to various fungi}

The effect of $\mathrm{pH}$ on copper toxicity for other fungi differed from that for Scytalidium sp. Whereas Scytalidium sp. failed to grow at neutrality or $\mathrm{pH} 4.0$ in media containing $4 \times 10^{-4}$ M-copper, all of the following fungi grew under these conditions (Table 3): Aspergillus flavus, A. niger, Penicillium notatum, P. simplicissimum, Trichoderma koningi, A. oryzae, Fusarium culmorum, F. oxysporum, Rhizopus nigricans, Monilinia fructicola, Stemphylium sarcinaeforme. The first five cultures grew in media containing $4 \times 10^{-4}$ to $4 \times 10^{-2} \mathrm{M}$-copper and having $\mathrm{pH}$ values of $2 \cdot 0$ to $7 \cdot 0$, except $P$. notatum that failed to grow at $\mathrm{pH} 2 \cdot 0$. The other six fungi were somewhat less tolerant to copper. The amount of growth decreased with increasing concentrations of copper sulphate. As with Scytalidium sp., the $\mathrm{pH}$ rose appreciably during growth in media having initial $\mathrm{pH}$ values of $7^{\circ} \mathrm{O}, 4^{\circ} \mathrm{O}$ and $3^{\circ} \mathrm{O}$. 
Copper tolerance of fungi

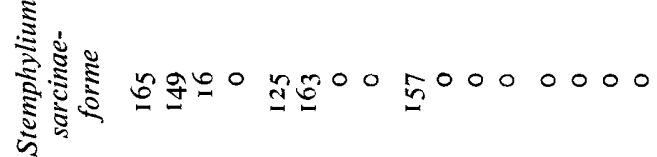

竎蓄

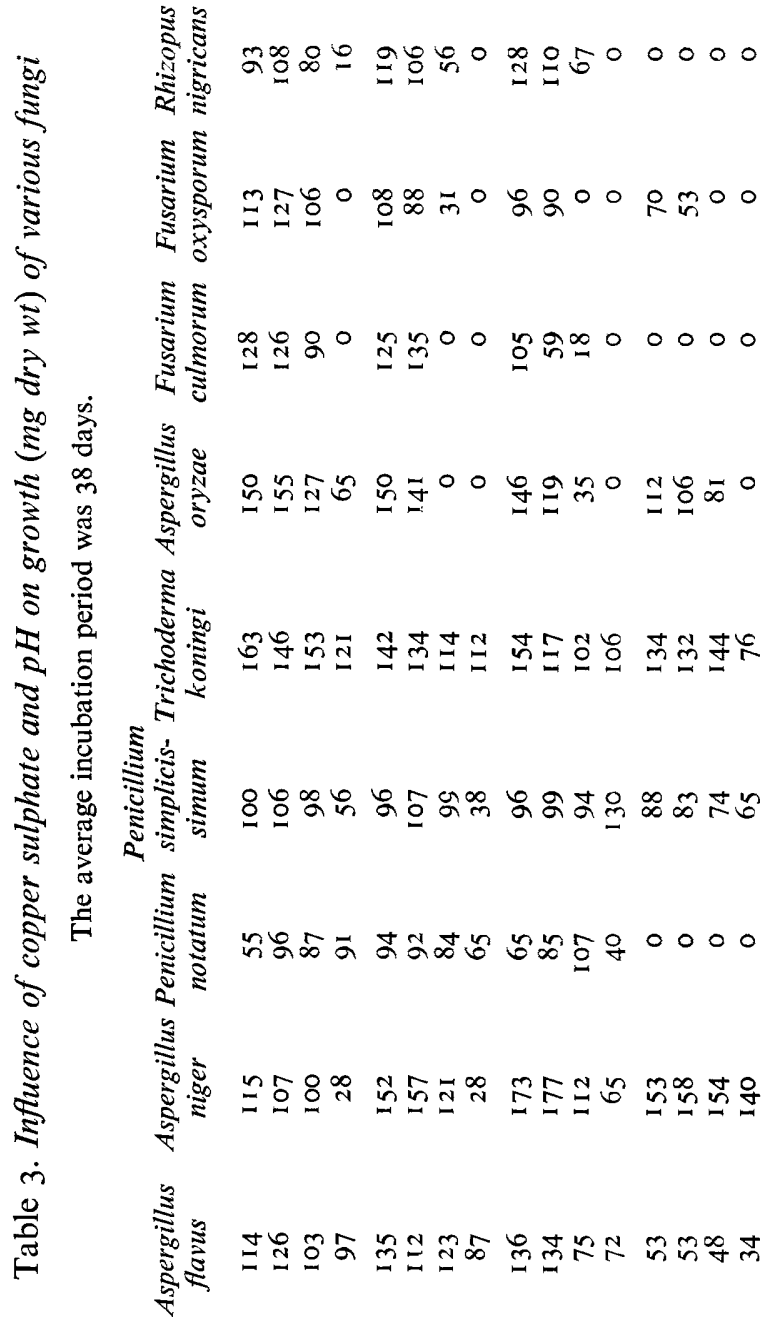

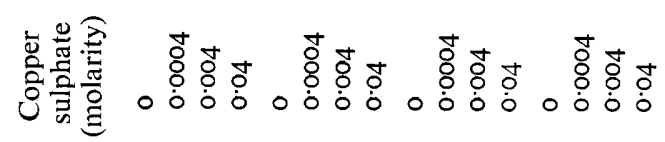

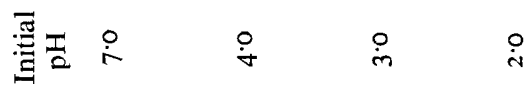


Table 4. Influence of oxine and copper sulphate on growth (mg dry wt) of Scytalidium sp.

The cultures were incubated $4 \mathrm{I}$ days.

\begin{tabular}{|c|c|}
\hline $\begin{array}{l}\text { Copper } \\
\text { sulphate } \\
\text { (molarity) }\end{array}$ & $\begin{array}{c}\text { Initial } \\
\mathrm{pH}\end{array}$ \\
\hline o to $4 \rtimes .10^{-4}$ & $7 \cdot 0$ \\
\hline $\begin{array}{l}0 \\
4 \times 10^{-6} \\
4 \times 10^{-5} \\
4 \times 10^{-4}\end{array}$ & 4.0 \\
\hline $\begin{array}{l}0 \\
4 \times 10^{-6} \\
4 \times 10^{-5} \\
4 \times 10^{-4}\end{array}$ & $3 \cdot 0$ \\
\hline $\begin{array}{l}0 \\
4 \times 10^{-8} \\
4 \times 10^{-7} \\
4 \times 10^{-6} \\
4 \times 10^{-5} \\
4 \times 10^{-4}\end{array}$ & $2 \cdot 0$ \\
\hline
\end{tabular}

\begin{tabular}{ccccc}
\multicolumn{5}{c}{ Oxine (molarity) } \\
\hline 0 & $7 \times 10^{-7}$ & $7 \times 10^{-6}$ & $7 \times 10^{-5}$ & $7 \times 10^{-4}$ \\
105 & 0 & 0 & 0 & 0 \\
135 & 166 & 0 & 0 & 0 \\
& 153 & 0 & 0 & 0 \\
& 34 & 0 & 0 & 0 \\
143 & 0 & 0 & 0 & 0 \\
& 175 & 146 & 0 & 0 \\
& 173 & 104 & 0 & 0 \\
83 & 160 & 49 & 0 & 0 \\
& 20 & 30 & 0 & 0 \\
& 101 & 103 & 86 & 68 \\
& 105 & 58 & 83 & 41 \\
& 101 & 56 & 90 & 54 \\
& 98 & 54 & 87 & 42 \\
& 95 & 66 & 84 & 25 \\
& 96 & 43 & 93 & 0
\end{tabular}

Unlike Scytalidium sp., all of the other fungi grew at neutrality in media with $4 \times 10^{-3} \mathrm{M}-$ copper and six of the eleven developed at neutrality with $4 \times 10^{-2} \mathrm{M}$-copper. None showed increased tolerance to copper with increase in acidity of the media. They were less tolerant to acidity than was Scytalidium sp., which grew in media as acid as $\mathrm{pH}$ o in absence of copper sulphate and at $\mathrm{pH} \mathrm{0.3}$ in a medium saturated with the salt (Starkey \& Waksman, I943). None of the other fungi grew at $\mathrm{pH} \mathrm{I} \cdot \mathrm{O}$ even in the absence of copper, and 4 cultures failed to develop at $\mathrm{pH} 2 \cdot 0$.

\section{Effect of oxine on copper toxicity for Scytalidium sp.}

Oxine was toxic in the absence of copper sulphate (Table 4), more so at higher pH values. Comparison of the data in Tables 2 and 4 indicates that oxine toxicity was dominant where both oxine and copper were present. Wherever there was growth, the $\mathrm{pH}$ rose as in previous experiments. Based on chelation of one atom of copper by 2 molecules of oxine ( $1: 2$ complex), there was more than sufficient oxine to chelate all of the copper at one or more concentrations of copper sulphate at each oxine level.

Tests were made also with the chelating agent EDTA with both Na-EDTA and Cu-EDTA at concentrations of $3 \times 10^{-3}$ and $3 \times 10^{-4} \mathrm{M}$. There was no evidence of reduction of copper toxicity by EDTA for Scytalidium sp. in media containing $4 \times 10^{-3} \mathrm{M}$-copper and having $\mathrm{pH}$ values of $0.5,2 \cdot 0,3.0$ and 6.0 . Furthermore, there was no evidence of toxicity of the chelating agent at these $\mathrm{pH}$ values in the absence of copper sulphate except that $3 \times 1 \mathrm{IO}^{-3} \mathrm{M}$ Na-EDTA inhibited growth at $\mathrm{pH} 3 \cdot 0$.

\section{Effects of salts of other heavy metals on Scytalidium sp.}

The fungus was grown in the glucose-nitrate medium containing several concentrations of the following compounds and at $\mathrm{pH} 7 \cdot 0,4 \cdot 0,3 \cdot 0,2 \cdot 0$ and $\mathrm{I} \cdot 0: \mathrm{FeCl}_{3} \cdot 6 \mathrm{H}_{2} \mathrm{O}, \mathrm{CoCl}_{2} \cdot 6 \mathrm{H}_{2} \mathrm{O}$, $\mathrm{CrCl}_{3} .6 \mathrm{H}_{2} \mathrm{O}$. In the media with high concentrations of ferric and chromic chlorides, there was considerable precipitation except at the most acid $\mathrm{pH}$ values. Table 5 shows that the 
Table 5. Growth (mg dry wt) of Scytalidium sp. in media with salts of heavy metals

Metal salts were added to the medium as indicated. The cultures were incubated 28 days.

\begin{tabular}{|c|c|c|c|c|c|}
\hline \multirow{2}{*}{$\begin{array}{l}\text { Concn of } \\
\text { metal salt } \\
\text { (molarity) }\end{array}$} & \multicolumn{5}{|c|}{ Initial $\mathrm{pH}$} \\
\hline & 7.0 & $4 \cdot 0$ & $3 \cdot 0$ & $2 \cdot 0$ & $1 \cdot 0$ \\
\hline o & I 35 & 95 & I 82 & 80 & 115 \\
\hline \multicolumn{6}{|c|}{$\mathrm{FeCl}_{3} \cdot 6 \mathrm{H}_{2} \mathrm{O}$} \\
\hline $5 \times 10^{-4}$ & I 29 & 150 & I96 & IC 3 & 147 \\
\hline $5 \times 10^{-3}$ & 113 & 216 & 235 & 167 & $6 I$ \\
\hline $5 \times 10^{-2}$ & $4 \mathrm{I}$ & 28 & 45 & 142 & 27 \\
\hline \multicolumn{6}{|c|}{$\mathrm{CoCl}_{2} \cdot 6 \mathrm{H}_{2} \mathrm{O}$} \\
\hline $5 \times 10^{-7}$ & I 29 & I 48 & I6I & I 33 & 92 \\
\hline $5 \times 10^{-6}$ & 9I & 130 & 178 & I 22 & 60 \\
\hline $5 \times 10^{-5}$ & I! & 46 & 75 & I3I & 101 \\
\hline $5 \times 10^{-4}$ & 0 & 0 & 0 & 0 & 0 \\
\hline \multicolumn{6}{|c|}{$\mathrm{CrCl}_{3} \cdot 6 \mathrm{H}_{2} \mathrm{O}$} \\
\hline $5 \times 10^{-7}$ & I19 & I 2 I & I 23 & 53 & I 16 \\
\hline $5 \times 10^{-6}$ & 82 & 90 & 125 & 40 & 112 \\
\hline $5 \times 10^{-5}$ & 65 & 43 & 149 & 43 & 108 \\
\hline $5 \times 10^{-4}$ & 48 & $4 \mathrm{I}$ & 158 & 69 & 122 \\
\hline $5 \times 10^{-3}$ & 49 & 30 & 102 & 153 & 121 \\
\hline
\end{tabular}

fungus was tolerant to relatively high concentrations of salts of these metals at all $\mathrm{pH}$ values. Cobalt was more toxic than iron or chromium. As in previous experiments growth in media with initial $\mathrm{pH}$ values of $3 \cdot 0,4 \cdot 0$ and $7 \cdot 0$ resulted in marked increase in $\mathrm{pH}$.

\section{DISCUSSION}

The unusual tolerance of Scytalidium sp. to copper was confined to acid media, as it grew in media saturated with copper sulphate at $\mathrm{pH} 2 \cdot 0$ to $0 \cdot 3$ (Starkey \& Waksman, I943), but it made practically no growth in media containing $4 \times \mathrm{IO}^{-4} \mathrm{M}$-copper with initial $\mathrm{pH}$ values of 4.0 or above. In media of $\mathrm{pH} 3.0$ containing $\mathrm{IO}^{-4} \mathrm{M}$-copper sulphate, the $\mathrm{pH}$ rose to less than $5^{\circ}$, but at lower concentrations of copper the $\mathrm{pH}$ rose much higher and there was more growth. The $\mathrm{pH}$ range of 4.2 to 5.0 appears to be the critical one for copper toxicity and possibly reflects the effect of $\mathrm{pH}$ on the uptake of copper, so that above $\mathrm{pH}_{4 \cdot 2}$ to $5^{\circ} \mathrm{O}$ copper could penetrate the cell but at the lower $\mathrm{pH}$ values copper uptake is reduced or ceases. Among the factors responsible for development of copper tolerance by fungi and yeasts, Ashida (1965) mentioned reduction in permeability, production of copper-binding compounds such as cysteine, and changes in certain metabolic and enzymatic activities. Possibly the reported tolerance of copper by the acidophilic cultures of sulphur bacteria of the genus Thiobacillus (Booth \& Mercer, 1963) is also caused by a lack of copper absorption at low $\mathrm{pH}$ levels.

The effect of $\mathrm{pH}$ has seldom been considered in studies of toxicity of copper to fungi. Bedford (1936) reported that a species of Penicillium was not affected appreciably by high concentrations of copper sulphate between $\mathrm{pH} 2.5$ and 6.4 but that there was no growth in alkaline media. I have found that various fungi, other than Scytalidium sp., tolerated high concentrations of copper in neutral and acid media. On the basis of development of pregrown mats of Penicillium lycopersici, Scott (1929) concluded that toxic cations, such as copper, were most inhibitory at $\mathrm{pH}$ greater than $5 \cdot 5$. From such results, Scott (I929) and Horsfall 
(I956) concluded that low $\mathrm{pH}$ lowers absorption of copper by fungi and so increases tolerance.

It is generally agreed (Martell \& Calvin, I952; Albert, Gibson \& Rubbo, 1953; Albert, Hampton, Selbie \& Simon, I954; Block, I955; Horsfall, 1956; Albert, I958, I968) that copper exerts its toxic effects within the cell, and Somers (1963, 1966) concluded that it enters the cell in combination with a carrier. His observation that pretreatment of conidia of Neurospora crassa with $0 . \mathrm{I} \mathrm{M}-\mathrm{HCl}$ reduced uptake and toxicity of copper, supports this conclusion. Unlike Scytalidium sp., all of eleven other fungi grew at neutrality at relatively high concentrations of copper sulphate. If copper enters the cell by means of a carrier, as proposed by Somers (1963, I966), it is possible that the carrier(s) of the eleven fungi was not the same as that in Scytalidium sp.

According to Martell \& Calvin (I952) toxicity of oxine is due to its combining with the metal attached to cellular enzymes and thus inactivating them. Others (Mason, I948; Vicklund, Manowitz \& Bagdon, 1954; Block, I955; Nordbring-Hertz, 1955) noted that oxine increases the toxicity of copper. My results show that, over a wide range of $\mathrm{pH}$ (3.0 to 7.0 ), oxine failed appreciably to increase copper toxicity to Scytalidium sp. and I found no evidence that Na- or Cu-EDTA at $3 \times 10^{-3}$ or $3 \times 10^{-4} \mathrm{M}$ reduced toxicity of copper at $\mathrm{pH} 0.5$ to $6 \cdot 0$. However, Horsfall (1956) has reported that EDTA can reduce copper toxicity.

The toxicity of oxine and copper sulphate to Scytalidium $\mathrm{sp}$. was lower at lower $\mathrm{pH}$ values. Copper forms one of the most stable of the metal oxinates (Irving \& Williams, 1948), but the complex becomes ionized at low $\mathrm{pH}$, when oxine and copper oxinate are least toxic (Fleck \& Ward, I933; Zentmyer, I944; Martell \& Calvin, I952; Block, I955; Horsfall, I956). Nordbring-Hertz (1955) stated that toxicity of both oxine and copper oxinate decreased with drop in $\mathrm{pH}$ and that the decrease was pronounced between $\mathrm{pH} 5.0$ and $4^{\circ} \mathrm{O}$.

Albert et al. (1953, 1954) and Albert (1958, 1968) concluded that oxine serves to transport the copper across the cell membrane as the $I: 2$ complex which persists in the presence of excess oxine but breaks down to the toxic I: I complex where there is no excess. However, the data in Table 4 show no consistent decrease in toxicity where there was excess oxine.

This is a paper of the Journal Series, New Jersey Agricultural Experiment Station, New Brunswick, New Jersey, U.S.A.

\section{REFERENCES}

AlberT, A. (1958). Metal-binding agents in chemotherapy: the activation of metals by chelation. In Symposium of the Society of General Microbiology 8, I $12-138$.

Albert, A. (1968). Selective Toxicity and Related Topics, p. 33I. London: Methuen.

Albert, A., Gibson, M. I. \& Rubbo, S. D. (1953). The influence of chemical constitution on antibacterial activity. 6. The bactericidal action of 8-hydroxyquinoline (oxine). British Journal of Experimental Pathology 34, II9-1 30.

Albert, A., Hampton, A., Selbie, F. R. \& Simon, R. D. (i954). The influence of chemical constitution on antibacterial activity. 7. The site of action of 8-hydroxyquinoline (oxine). British Journal of Experimental Pathology 35, 75-84.

Ashida, J. (1965). Adaptation of fungi to metal toxicants. Annual Review of Phytopathology 3, I53-1 74.

BEDFord, C. L. (1936). Morphological and physiological studies upon a Penicillium sp. tolerant to copper sulfate. Zentralblatt für Bakteriologie, Parasitenkunde, Infektionskrankheiten und Hygiene (Abteilung II) 94, IO2-I12.

BLock, S. S. (1955). Fungitoxicity of the 8-quinolinols. Journal of Agricultural and Food Chemistry 3, $229-234$. Booth, G. H. \& Mercer, S. J. (1963). Resistance to copper of some oxidizing and reducing bacteria. Nature, London 199, 622. 
Brooks, B. T. (19I4). Note on antiseptics. Journal of Industrial and Engineering Chemistry 6, 958-959.

Bryner, L. C., Beck, J. V., Davis, B. D. \& Wilson, D. G. (I954). Micro-organisms in leaching sulfide minerals. Industrial and Engineering Chemistry 46, 2587-2592.

Ellis, M. B. (1971). Dematiaceous Hyphomycetes, p. 28. Kew, Surrey: Commonwealth Mycological Institute.

FLECK, H. R. \& WARD, A. M. (1933). The determination of metals by means of 8-hydroxyquinoline. Analyst 58, 388-395.

Horsfall, J. G. (1956). Principles of Fungicidal Action. Waltham, Massachusetts: Chronica Botanica.

Hubert, B. (1938). Copper tolerance of Penicillium Waksmani Zaleski. Biologisch Jaarboek. Koninklijk Natuurwetenschappelijk Genootschap Dodonaea te Gent 5, 326-329.

Irving, H. \& Williams, R. J. P. ( I948). Order of stability of metal complexes. Nature, London $\mathbf{1 6 2 ,} 746-747$.

Jurkowska, H. (1952). The adaptation of Aspergillus niger to copper. Acta microbiologica polonica 1, I07122.

Kuznetsov, S. I., Ivanov, M. V. \& Lyalikova, N. N. (1963). Introduction to Geological Microbiology. New York: McGraw-Hill.

Marchlewitz, G., Hasche, D. \& Schwarz, W. (I96I). Untersuchungen über das Verhalten von Thiobakterien gegenüber Schwermetallen. Zeitschrift fïr allgemeine Mikrobiologie, Morphologie, Physiologie und Oekologie der Mikro-organismen $\mathbf{1}, \mathrm{I} 79-\mathbf{1} 8 \mathrm{I}$.

Martell, A. E. \& Calvin, M. (I952). Chemistry of the Metal Chelate Compounds. New York: Prentice-Hall.

MAson, C. L. (1948). A study of the fungicidal action of 8-quinolinol and some of its derivatives. Phytopatho$\log y \mathbf{3}, 740-75 \mathrm{I}$.

Nordbring-Hertz, B. (1955). Studies on growth and inhibition of Candida albicans. Physiologia plantarum $8,69 \mathrm{I}-7 \mathrm{I} 7$.

Pulst, C. (1902). Die Widerstandsfähigkeit einiger Schimmelpilze gegen Metallgifte. Jahrbuch für wissenschaftliche Botanik 37, 205-263.

SATo, T. (1939). Studies upon the molds growing in high concentrations of sulfuric acid and copper sulfate. Journal of the Agricultural Chemical Society of Japan 15, 359-369.

Scotт, I. T. (1929). Hydrogen-ion equilibrium on mycelium mats of Fusarium lycopersici in salt solutions and its relation to growth and toxicity. American Journal of Botany 16, 63 I-643.

Somers, E. ( 1963). The uptake of copper by fungal cells. Annals of Applied Biology 51, 425-437.

Somers, E. (1966). The site of reaction of fungicides in spores. In The Fungus Spore, pp. 299-306. Edited by M. F. Madelin. London: Butterworths.

Starkey, R. L. \& Waksman, S. A. (1943). Fungi tolerant to extreme acidity and high concentrations of copper sulfate. Journal of Bacteriology 45, 509-5 I9.

Sutton, J. A. \& CoRRick, J. D. (1963). Leaching of copper minerals by means of bacteria. Mining Engineering $\mathbf{1 5}, 37-40$.

Trabut, M. L. (i 895). Sur un Penicillium végétant dans des solutions concentrées de sulfate de cuivre. Bulletin de la Société Botanique de France 42, 33-34. (See Annual Review of Phytopathology, I965, 3, I $53-174$.

Vicklund, R. E., Manowitz, M. \& Bagdon, V. J. (I954). Mechanism of action of copper 8-quinolinolate. Mycologia 46, I33-I42.

Villedieu, G. \& Villedieu, G. (I920). De la non-toxicité du cuivre pour les moisissures en général et pour le mildiou en particulier. Comptes rendus hebdomadaire des séances del'Académie des sciences 17 I, 737-739.

Zentmyer, G. A. (1944). Inhibition of metal catalysis as a fungistatic mechanism. Science, New York roo, $294-295$. 